\title{
If the Song has No Price, is it Still a Commodity? Rethinking the Commodification of Digital Music
}

\author{
By Rasmus Fleischer
}

\begin{abstract}
In music streaming services like Spotify, discrete pieces of music no longer has a price, as has traditionally been the case in music retailing, both analog and digital. This article discusses the theoretical and practical implications of this shift towards subscriptions, starting from a critical review of recent literature dealing with the commodification of music. The findings have a relevance that is not limited to music or digital media, but also apply more broadly on the study of commodification. At the theoretical level, the article compares two ways of defining the commodity, one structural (Marx), one situational (Appadurai, Kopytoff), arguing for the necessity of a theory that can distinguish commodities from all that which is not (yet) commodified. This is demonstrated by taking Spotify as a case, arguing that it does not sell millions of different commodities to its users, but only one: the subscription itself. This has broad economic and cultural implications, of which four are highlighted: (1) The user of Spotify has no economic incentive to limit music listening, because the price of a subscription is the same regardless of the quantity of music consumed. (2) For the same reason, Spotify as a company cannot raise its revenues by making existing customers consume more of the product, but only by raising the number of subscribers, or by raising the price of a subscription. (3) Within platforms like Spotify, it is not possible to use differential pricing of musical recordings, as has traditionally been the case in music retail. Accordingly, record companies or independent artists hence can no longer compete for listeners by offering their music at a discount. (4) Within the circuit of capital. Spotify may actually be better understood as a commodity producer than as a distributor, implying a less symbiotic relationship to the recorded music industry.
\end{abstract}

Keywords: capital, commodification, commodity-form, digital distribution, media industries, music, political economy, reification, Spotify, streaming, subscriptions.

Fleischer, Rasmus: "If the Song has no Price, is it Still a Commodity? Rethinking the Commodification of Digital Music", Culture Unbound, Volume 9, issue 2, 2017: 146-162. Published by Linköping University Electronic Press: http://www.cultureunbound.ep.liu.se 


\section{Introduction}

The concept of commodification ${ }^{1}$ is widely used in the humanities and social sciences. Searching Google Scholar for the phrase "the commodification of" returns hundreds of titles asserting that culture as well as nature has been subject to the same process; the list of things commodified includes language, health, education, security, the body and the past. This article will review some recent literature on the commodification of music, but the findings have a broader relevance for attempts to study the political economy of digital media, and streaming services in particular. On a theoretical level, the aim is to sharpen the concept of commodification, which many scholars tend to use in a rather loose sense, sometimes synonymous with commercialization.

In more specific cases, the meaning of commodification might at first glance seem simple: something which is not a commodity then becomes one, typically by having a price tag attached to it. But this process tends not to leave the 'thing' untouched. In a longer historical perspective it stands clear that 'the commodification of music' does not simply indicate that a thing called 'music' is brought into the marketplace from the outside-the process also redefines the very meaning of 'music' (Fleischer 2012: 76-103).

In the tradition of critical theory, commodification is usually considered to be a "structural tendency in capitalism" (Jameson 2009: 257). A different approach is taken by cultural anthropologists who understand commodification as a "cultural and cognitive process" (Kopytoff 1986). In any case, speaking of commodification as a tendency or a process seems to necessitate a theory that can distinguish commodities from all that which is not (yet) commodified. Such a distinction, it may be noted, was pivotal to Karl Marx' analysis of the capitalist mode of production. While he did begin Capital with a discussion of the commodity-form, his critique of political economy was conditioned on the observation that the classical economists were wrong in defining labour as a commodity. ${ }^{2}$ But after him, critical theorists have usually been more keen to denounce commodification than to delineate it. This article will argue for the importance of having a precise concept of the commodity when trying to understand the political economy of digital media. Using the streaming music service Spotify as a case, my argument will be put forward in dialogue with some recent literature dealing with the commodification of music.

\section{Perspectives on the Commodification of Music}

Ten years ago, ethnomusicologist Timothy D. Taylor remarked about the lack of theoretical treatments of how music is commodified. The commodity status of popular music, he wrote, "is so common that it seems to be self-evident, even 
natural" (Taylor 2007, cf. Taylor 2006). Yet at the time of that observation, many observers regarded the practice of online file-sharing as subverting the commodification of music (Söderberg 2008: 8). The recorded music industry still betted on the success of digital retailers like Apple's iTunes Store, selling music in the form of single-track downloads (IFPI 2007). But since then, the industry has been transformed anew by the rise of subscription-based streaming music services like Spotify.

This trajectory of music's digitization has also inspired a new body of research, mostly within media studies, addressing how music is today put on the market. This literature can broadly be divided in two categories. On the one hand are the industry-oriented researchers who do not pretend to be critical, and whose research is chiefly based on interviews with music industry professionals. Their accounts tend to naturalize the commodity, asking not how music is commodified, but how the music commodity can be successfully "monetized" (Wikström 2009, Waelbroeck 2013, Johansson 2013, Galuszka 2015) On the other hand are those scholars who analyze the digitization of music through the lens of media history, zooming in on particular media formats, interfaces, affordances and social practices. Jonathan Sterne's book MP3 (2012) was pathbreaking in this respect; a similar approach has recently been taken by Jeremy Wade Morris in Selling Digital Music (2015) and also, to some degree, by the above-mentioned Timothy D. Taylor in Music and Capitalism (2015).

The latter three books share a similar approach to the concept of commodification. On the one hand, they all use the distinctly Marxian term commodity-form, though in a sporadic manner (Sterne 2012: 224, Morris 2015: 2, 213, Taylor 2015: 20-26) At the same time, all three books also rely to some degree on the influential theories of cultural anthropologists Arjun Appadurai and Igor Kopytoff, regarding how 'things' can move in and out of the commodity-state (Sterne 2012: 212-216, Morris 2015: 9-10, Taylor 2015: 10-11). These are two very different approaches, but none of the three authors provide any discussion about how to reconcile them - and in the end, none attempts to systematically apply any of the two theories on the turbulent reality of a digitizing music industry. The concept of commodification thus remains oddly undertheorized in the recent books by Sterne, Morris and Taylor. Taylor (2015, 21-24) does introduce a useful concept, "regimes of commodification", identifying three in the history of commodified music:

We can consider music to exist in different regimes of commodification, all of which are still with us, though some are residual, some dominant, and some emergent: music as a published score, music as live sound at a public concert, and music as recorded sound in the form of player piano rolls or audio recordings in many other formats, analog or digital. (Taylor 2015: 21) 
According to Taylor, all media technologies involving recorded sound belong to the same regime of commodification. ${ }^{3}$ Morris, on the other hand, identifies a clear break between analog and digital: "The digital music commodity marks an evolution of the commodity-form" (Morris 2015: 11). What these two accounts have in common is that they rule out any substantial shift within the digital. Both authors are implicitly assuming that a download service like iTunes Store and a streaming service like Spotify are basically selling the same commodity, albeit in different wrappings.

This becomes especially problematic in the case of Selling Digital Music, as Morris claims to have written not a study of particular media but an inclusive analysis of "the digital music commodity", and that his findings can be generalized as to apply for cultural commodities other than music. Throughout the whole book it is taken for granted that each file or song is a commodity. That makes sense when looking at a retailer like iTunes Store, where an apparent price tag is put on every single song. But pricing works very differently on streaming services like Spotify. In the latter case, an ordinary user will confront only one single price tag: 9.99 USD/EUR/GBP for a monthly subscription.

Only a few years ago, many economists and business journalists took for granted that internet would be 'the great unbundler': Instead of charging for a package, each item would be offered to consumers as a separate product. As a prime example of unbundling, these commenters pointed to Apple's iTunes Store, selling singular tracks instead of albums (Akst 2005, Styvén 2007: 68, Carr 2008: 149-156, Elberse 2010, Pakman 2011). But this was soon followed by a massive re-bundling, as companies like Spotify began selling music as a subscription service. Instead of music being marketed as discrete units, each with one price tag, there is now only one product on offer: the subscription. As individual songs are made available within Spotify's interface, without having any individual price, does it make sense to regard each song as one commodity? If not, in what sense is music commodified? Why does the theorization of the commodity matter for understanding the relationship between production and distribution, or the role of digital platforms, within contemporary capitalism?

These are the questions that I will attempt to answer in this article. Before entering a critical dialogue with Morris, I will take one step back for a brief reconstruction of the two abovementioned approaches to theorizing the commodity; on the one hand, the Marxian critique of political economy, on the other hand, the biographical approach of cultural anthropology. This will allow me to demonstrate how the theorization of the commodity matters, whether the focus of interest is music listening patterns, media business dynamics or the overall structure of digital capitalism. 


\section{Critical Theory \& the Commodity Form}

'Commodify' is a relatively new verb. It was not established in English until the mid-1970s, probably as a translation of the Marxian expression "zur Ware werden" (Rose 2005, Haug 2010, Beech 2015: 231). Since then the term has made a rapid career in critical theory with Georg Lukács, Guy Debord and Karl Polanyi frequently invoked along Karl Marx as the classic theorists of commodification, though none of them ever used the term.

Marx did indeed dedicate the first chapter of Capital to an analysis of the commodity-form, describing it as the "economic cell-form" of the capitalist mode of production. Half a century later, in 1923, this line of analysis was dramatically amplified by George Lukács, declaring "the commodity-structure" to be the sole ground for "all the objective forms of bourgeois society together with all the subjective forms corresponding to them" (Lukács 1923/1971: 83). It is hard to overstate the significance of this intervention for the newly founded Frankfurt School and for what would be known as Western Marxism.

In this tradition of dialectical critique, the distinction between form and content is of highest importance. The commodity's content might be a material object or an immaterial service, which gives it a particular use-value. But having a usevalue is not enough. In order for something to take on the commodity-form, it must also have an exchange-value, i.e. it must stand in a market relation to other commodities. While the commodity is initially presented by Marx as the unity of use-value and exchange-value, this should not be mistaken for a final definition (a mistake made, for example, by Morris in Selling Digital Music). The Marxian critique of political economy is premised on categories - like commodity, value, labour and capital - whose interdependence can be properly deciphered only at the highest level of abstraction, as categories of a historically specific totality, commonly known as capitalism. Capitalism revolves around the abstraction of time, as commodity-producers compete with each other over minimizing the labour-time necessary in production (Postone 1993, Kurz 2012, Heinrich 2012). This process of abstraction is mediated by money. In chapter 3 of Capital, Marx (1867/1962: 109) declares money to be the "necessary form of appearance" for the abstracted labour-time. The fully developed commodity-form presupposes the existence of money. To put it very short, the Marxian definition of a commodity supposes that it has a price. On the other hand, it is not limited to tangible objects, but the commodity can as well be a service.

The analysis of the commodity-form does not end with the first chapter of Capital, as has often been assumed. It is not even completed in the first book. In book two of Capital, Marx proceeds from the economic cell-form to the circuit of capital. Here commodities and money appears as mere intermediary steps in an seemingly endless process of growth for growth's sake. Capital for Marx is 
not a thing, but can only exist in movement. The circuit presented by Marx has three stages and can be written out as a formula: $\mathrm{M}-\mathrm{C} \ldots \mathrm{P} \ldots \mathrm{C}^{\prime}-\mathrm{M}^{\prime}$. In the first stage, money $(\mathrm{M})$ is used to buy commodities $(\mathrm{C})$ : means of production and labour-power, together forming productive capital $(\mathrm{P})$. The second stage consists of "productive consumption" in which the acquired commodities disappear in the creation of new commodities "of more value than that of the elements entering into its production". In the third and final stage, the commodity-producer "returns to the market as a seller", and capital is once again metamorphosing into money - the whole point being that there will now be more money than at the outset (Marx 1885/1963: 31). Every step in the process, however, implies a risk of capital's devaluation. The value entering production will be conserved, and a surplus value added, only if the commodity producer succeeds in predicting the market correctly, so that the commodities can actually be sold at a profitable price (Manzerolle \& Kjøsen 2012).

At the center of this circuit - right in the middle of production - Marx finds a form of consumption. This "productive consumption" is not to be confused with individual consumption, which occurs outside the circuit of capital. Productive consumption means, for example, that raw materials are used up, that machinery and buildings are gradually worn down, and that the human time put into labour will never return again. But the capitalist mode of production, according to Marx, is organized so that value can be transferred from a preexistent commodity to a newly produced one. For something intangible (i.e. labour-power, care, knowledge, risk, or music) to become a commodity, it must first be transformed into an object. In critical theory, following Marx and Lukács, such objectification is known as reification. Thus, reification is a prerequisite for commodification, but does not in itself entail it. Fredric Jameson is consistent with Marx in concluding that it "is the market price which alone stamps an object as a commodity" (Jameson 2009: 257).

Proceeding from this, Jameson observes that in today's academia, the analysis of commodification tends to diverge into two separate projects. On the one hand we find "abstract philosophical evocations" of "the organization of reality into things"; on the other, "specific empirical studies of the operations of markets in various fields" (Jameson 2009: 257-259). Bridging this theoretical gap is an important enterprise, to which Sterne, Morris and Taylor all contribute, to some degree. But this should not come at the expense of a blurred distinction between commodities and other objects.

If the commodity is defined by having a price, it should be fairly simple to tell whether a tangible object is commodified or not. But what about something like music? As a human practice, music can undoubtedly be subjected to different regimes of commodification, grounded in different modes of reification. This even 
includes the possibility of commodification as resistance. Theodor W. Adorno saw modernist art as characterized by an attempt to turn commodification against itself (Martin 2007). If capitalism implies the tendential commodification of the entire social field, the modern artwork can, in Jameson's words, "only resist this external commodification by commodifying itself from the inside, by making itself over into a strange kind of mirror-commodity which is also an anti-commodity" (Jameson 2009: 264). Such an impulse might even be discerned in the "postdigital" tactics in some of today's musical subcultures; the commodification of material objects (like vinyl or cassettes) as an act of resistance against the attempts of platforms like Spotify to "commodify the void created by the lost materiality of music" (Fleischer 2015). In any case, the point of critical theory cannot be to just detect and denounce commodification in sweeping terms. One must always ask, what kind of object is made a commodity, before asking how it is done and how it can be possibly undone.

\section{Cultural Anthropology and the Commodity Situation}

A different way of defining commodities can be found in the two contributions to the seminal volume The Social Life of Things by anthropologists Arjun Appadurai (1986) and Igor Kopytoff (1986). Their joint intervention aimed at discarding the structural analysis of the commodity-form in favour of the 'biographic' approach of "following the thing". The central idea is that an object, during the course of its 'social life', can be traced as it is "moving in and out of the commodity state" (Appadurai 1986). In other words, the commodity is not understood as a material thing, nor as a metaphysical form, but as a temporal phase in the life of a thing.

It cannot be denied that a strong "tangibility bias" is inherent in the approach of Appadurai and Kopytoff. Applying the biographical method to less tangible objects may cause confusion. In the current context, for example, it is far from certain how to interpret a music stream, i.e. a data sequence, as a 'thing. Should the hardware device, the software interface and the sonic output then be regarded as three separate things, or as different aspects of the same thing? And while the metaphor of 'life' seems to imply birth and death, it remains unclear how to locate the beginning or the end of a thing's social life. Arguably, these uncertainties follow from the strong emphasis on exchange in this approach, as opposed to the Marxian emphasis on production (as productive consumption). David Graeber has also criticized Appadurai for "writing as if all exchanges are simply about things and have nothing to do with making, maintaining, or severing social relationships" (Graeber 2001: 32).

These problems notwithstanding, the essays by Appadurai and Kopytoff do provide clear criteria for deciding if a given object is in "the commodity state" 
or not. Decisive is the kind of situation in which the object is currently found. According to Appadurai, "the commodity situation" is characterized by the need to sacrifice one object in order to access another one. In a modern economy, such exchange tends to involve money, although other forms of commodity exchange may also be found. As an alternative to the Marxian emphasis on production, Appadurai draws on Georg Simmel's attempt to define "economic objects" based on their exchangeability:

Economic objects /.../ exist in the space between pure desire and immediate enjoyment, with some distance between them and the person who desires them, which is a distance that can be overcome. The distance is overcome in and through economic exchange, in which the value of objects is determined reciprocally. That is, one's desire for an object is fulfilled by the sacrifice of some other object. (Appadurai 1986)

This emphasis on situation and context does not suffer from the abovementioned tangibility bias, but can be used as a benchmark to judge the "commodityness" of digital objects within a certain interface.

\section{Downloading, Streaming \& Commodification}

The preceding sections have presented two alternative theorizations of the commodity. These do not directly contradict each other, but approach the problem from very different angles. For the anthropologists, commodityness is all about the individual thing in a particular situation: if the thing can be enjoyed immediately, without the need to give up something else, it is simply not a commodity (though it may re-enter the commodity state at any time). From a Marxian perspective, on the other hand, the commodity must always be considered as part of a circuit, centred around the act of productive consumption; commodities are produced by way of other commodities, in order to be sold.

I will not attempt to reconcile these two approaches, but keep them both in mind as I proceed to revisit the notion of the music commodity. To put things in context, I will first provide a brief comparison of five modes of accessing music online (as of 2017), based on the assumption that you want to listen to one particular song. The simple question posed here will be if this song is delivered to you as a commodity.

1. If you choose to download the song from a digital retailer like iTunes Store, you will first have to pay its price. The price of each song is usually set at 0.99 USD/EUR/GBP, but may be higher or lower; a new release by a big artist may be priced higher due to high demand. 
2. Alternatively, you can use a file-sharing network like Soulseek and download the song for free. The software for using this network does not expose the user for any advertising, and according to its developers, it is entirely financed by donations (Reitman 2016).

So far, the distinction seems clear: in the first case, the song is evidently a commodity, but not in the second. Matters however become a bit more complicated if you, instead of downloading a file to your computer, choose to stream the song directly from one of the many streaming services available. ${ }^{4}$

3. If you find the song on YouTube, you can listen to it for free, but it is quite likely that you will first be served an advertisement video. In this case, it is not the song itself that is sold to you, but your attention that is sold to advertisers. This kind of commodification is associated with the notion of the "audience commodity", established by Dallas Smythe in the 1970s (Morris 2015: 99-100). At a metaphorical level, it does make sense to say that you "pay" for the song with your attention, or with the behavioural data that YouTube is collecting on you, but in strictly economic terms you are not paying for a commodity - rather you are the commodity being sold.

4. Just like in the previous case, Spotify Free offers streaming music at no charge but with interruptions for advertisement. Spotify does indeed differ from YouTube in several respects: it is centred around music, not video; it does not invite anybody to upload content; it is only available to registered users. None of these differences seem to alter the basic mechanism of commodification. But a closer examination may indicate that advertisement fulfils partly different functions in the two services. Advertisers are indeed paying Spotify have a message delivered to an audience, but in Spotify's current "freemium" business model, advertisement revenues are arguably less important than the annoyance that users experience when the music is interrupted by ads. The main function of the ads is to prompt users to pay for a subscription.

5. In order to listen to music without interruptions, you can subscribe to Spotify Premium for a monthly 9.99 USD/EUR/GBP. In fact, this price is the only price that will ever confront an ordinary user of Spotify. The one and only commodity sold to consumers by Spotify is the subscription. The song itself is simply not delivered as a commodity to users of Spotify. It does not exist in what the cultural anthropologists would call a commodity-situation. As it does not have a price, it also does not fulfil the Marxian definition of a commodity. 


\section{The File-Centric Understanding of the Digital Music Commodity}

Jeremy Wade Morris' recent book Selling Digital Music (2015) is in many ways an excellent tracing of "the music commodity's re-tuning" in the transition from "compact discs to music as individual digital files" (Morris 2015: 2, 198-199). Settling there, however, it consolidates a particular kind of atomism, what I would call a file-centric understanding of the digital music commodity. This is problematic, since the author claims a broad validity of his findings, not only for every digital music service, but for "the process of cultural commodification" in general (Morris 2015: 5). "The digital music commodity is an object in its own right", and "a discrete sonic entity", Morris postulates at the outset. (Morris 2015:3,16) Throughout the book it is taken for granted that this commodity is essentially a file, representing a song (Morris 2015: 11, 192, 209-210) Sometimes the digital music commodity is equated with the simple audio data, other times it is presented as a bundle of audio data and metadata. What is never questioned is the notion of the song as musical atom being the object of commodification.

The interface, consisting of hardware and software, is what makes this object visible and audible, Morris writes: "It is the point where user and commodity meet." (Morris 2015: 18) In other words, the interface is not analysed as a commodity, nor as a commodifying device, but rather appears as an arena where the already commodified objects appear. This raises a substantial question about the definition of a commodity. Though he employs the Marxian notion of the commodity as form, Morris distances himself from Marx by stating that price "is not its distinguishing feature" (Morris 2015: 2, 8, 11, 20, 192, 210-213). And when looking for "the very core of the commodity", he finds not form but matter: a data file in a particular format (Morris 2015: 195). This view seems to be more in line with the anthropology of material culture, and early in the book Morris does indeed evoke Appadurai and Kopytoff to define commodities "as artifacts in a particular situation, the commodity situation" (Morris 2015: 9-10). But in his subsequent analysis of digital interfaces, Morris abstains from asking whether such a situation is at hand. At certain points, he follows a wholly different path, defining the commodity neither as form nor as situation, but by reference to a subjective "sense of ownership" (Morris 2015: 20). This theoretical confusion results in an inability to ever state that something is not a commodity. Ultimately, Selling Digital Music fails at its explicit aim: telling the "story of how the commodity form changes through digitization and why this matters for the music and media we love" (Morris 2015:2).

Morris seems to assume that it is the same commodity which is made available by "iTunes, Spotify, and many other digital retailers" (Morris 2015: 210). The formulation reveals a further assumption, namely that Spotify is essentially a retailer, i.e. a distributor of commodities that has already been produced el- 
sewhere. Retailing implies buying commodities in order to resell (or rent out) the same commodities. If a company is selling commodities different from those it has bought, it is evidently involved in some kind of production. But the distinction between production and distribution does not appear in Selling Digital Music, due to the lack of a clearly defined notion of the commodity. Whether a streaming service's activities are regarded as distribution or production does however have analytical repercussions.

In this section my argument has been developed as a critique of some implicit assumptions in Selling Digital Music. Now it is time to turn towards self-critique. After all, this article comes out of a research project about Spotify with the outspoken aim of 'following files in digital music distribution'. But what if, as already indicated, Spotify is better understood not as a music distributor but as a producer? Then a new question will arise: what commodity is Spotify producing?

\section{Producing the Branded Musical Experience}

Spotify began as a streaming service based on the on-demand doctrine, tailored for individuals who already knew exactly which pieces of music they wanted to hear: "Millions of tracks, any time you like [...] Just help yourself to whatever you want, whenever you want it." This was soon to change (Fleischer \& Snickars 2017). In 2013 the company adopted a new slogan: 'The right music for every moment. The current aim is to provide a programmed soundtrack to each 'moment' of the user's day. Asked to explain the core of his business, Spotify's CEO Daniel Ek explains: "We're not in the music space-we're in the moment space" (Seabrook 2014). This is part of a wider shift that has been brilliantly analyzed by Jeremy Wade Morris in a recent article co-authored with Devon Powers. Spotify and other "outlets that once primarily concerned themselves with distribution are now increasingly in the business of promotion, curation, user experience and analytics", they write. These services want to sell "music as an affective experience rather than as individual songs" (Morris \& Powers 2015).

Indeed, streaming services are not the first to commodify music by embedding it in a broader 'experience. One need only to think about music festivals, MTV, or Apple's marketing of the iPod. Still, the mechanism of commodification does differ between digital music services. Apple's iTunes uses the experience to sell commodified pieces of music, each piece being a commodity with a price. Spotify uses the music to sell a commodified experience, bundled together as one commodity. As already stated, the main problem with Selling Digital Music is that Morris here postulates a uniform logic of "the digital music commodity". The article co-written by Morris and Powers, on the contrary, points towards a transformed commodity-structure within the digital. 
Ultimately, we suggest that digital music services no longer sell discrete musical objects, nor do they focus exclusively on content offerings. Instead, services sell branded musical experiences, inviting consumers to see themselves and their attitudes, habits and sentiments about music reflected by the service they choose to adopt. (Morris \& Powers 2015)

It can be noted, however, that the concept of 'the music commodity', so prominent in Selling Digital Music, is all but absent in the recent article by Morris and Powers. It deserves to be re-introduced in the context of branded musical experiences, so that the transformed commodity-structure of digital music can be properly situated within the circuit of capital.

\section{Conclusions}

Music may be commodified in several ways: as published score, as live performance, as recorded sound. These are the three "regimes of commodification" mentioned by Timothy D. Taylor. However, the argument can be made that streaming music services like Spotify represent yet another regime. This fourth regime of commodification - music as part of a branded experience - is not new, but it may be argued that it is now becoming dominant. When music is not sold as individual pieces or events but is embedded in a personalized service, the distinction between production and distribution tends to blur. To enable a critical analysis of commodification it is necessary to first ask what commodity that is actually being sold to consumers, in this case by Spotify.

In this article, I have criticized Jeremy Wade Morris' concept of 'the digital music commodity' because it assumes that each song, whether it is downloaded or streamed, is distributed as a commodity. In the case of download retailers like iTunes Store, that is correct. But the user of Spotify will never see a price tag on a song, and never need to give up anything in order to consume one more song. Accordingly, the user of Spotify does not consume each song as a commodity. That is the only possible conclusion, whether one prefers to define the commodity structurally (Marx) or situationally (Appadurai, Kopytoff).

Spotify is indeed not selling discrete pieces of recorded sound, neither by the song, by the album, or in any other portioning. It is not putting millions of commodities on the market, but offering consumers only one commodity: the subscription. This product is a bundle that includes not only access to all songs in the catalog but also the maintenance of a personalized profile connected to a variety of playlists tailored for pre-defined activities, helping the user to navigate through an abundance of music without first having to choose which songs to play. This 
marks a clear difference to music retailers, analog or digital, which simply sell pieces of recorded music. While these retailers are indeed in the business of music distribution, streaming services are moving away from the distributive function, attempting to occupy another place in the circuit of capital. Currently it may make more sense to regard Spotify as a commodity producer.

According to Karl Marx, commodity production includes the "productive consumption" of labour-power and means of production. In order to produce the "branded musical experience", Spotify has to acquire on the one hand labour-power (from network engineers to graphic designers and music curators), and on the other hand, means of production (including hardware, bandwidth, and music licenses). Of all these expenses, music licenses make up the by far largest part. The productive consumption of licenses does also put a limit to the possible economies of scale. For every new user, Spotify has to pay money to the rights holders, though the details of the licensing deals are trade secrets, unavailable for independent researchers.

When regarded as a commodity producer, Spotify seems to have more in common with traditional broadcasters than with any sort of music retailer. The radio listener also does not receive commodities over the air when music is played - rather, music is used to harness the attention of the listener in the production of the audience commodity that is sold to advertisers. For this, the radio broadcaster has to buy a music license from a copyright collecting society, and the pricing of this license does not discriminate between different pieces of music; typically, a flat fee is paid by the minute. Economically, this is very different from the record shop (or the download shop), where a new and popular recording may cost more than an old one. If radio broadcasters and record shops represented two different regimes of commodification in the 20th century, Spotify's business model may be better understood as a mutation of the traditional broadcasting model than as a new form of retail.

It can hardly be denied that Spotify is a heavily commodified environment. But compared to the selling of individual songs by retailers like iTunes Store, streaming services like Spotify have a very different way of commodifying music. The decommodification of individual recordings (at the consumer's side), now coincides with the recommodification of music as an experience. This shift in music's commodity structure does indeed matter for the individual music listener, just like it matters for a company like Spotify, and for the recorded music industry at large. Furthermore, it has repercussions for the broader analysis of how to situate digital platforms in the circuit of capital. I will sum up this article by briefly motivating these four points.

1. The user of Spotify does not confront songs or albums as commodities. The only commodity the user is invited to consume is the subscription itself. Everybo- 
dy pays the same monthly fee to access the same service. When listening to music on Spotify as a subscriber, there is no longer a commodity-situation at hand, hence no incentive to limit music listening, neither as in listening time, nor as in number of songs accessed.

2. This commodity-structure also determines the possibility of growth for a company like Spotify. There is no real point for it to make existing subscribers consume more music, as these will pay the same amount per month regardless if they listen to 10 or 10,000 songs. The two remaining ways to increase revenue would then be to raise the cost of a subscription, or to raise the number of subscribers.

3. For the recorded music industry, this creates different incentives as compared to the sale of music as discrete units. Most importantly, it removes the possibility for differential pricing. As long as discrete units of music are sold to consumers via a distributor, a new or exclusive recording can be made more expensive, while an upcoming artist can choose to offer music much cheaper, or at no cost at all, thereby gaining a better chance to compete. Even a digital retailer like iTunes Store allows for a limited degree of differential pricing, but Spotify does not. Price competition has now been effectively abolished. The rights holder cannot try out different pricing strategies, but only choose whether to be on the platform or be absent. ${ }^{5}$

4. It has usually been taken for granted that the record industry produces a commodity, which is then distributed by services like Spotify. This could imply a symbiotic relationship based on a shared interest in keeping up the value of recorded music. Matters appear a bit different if Spotify is instead considered a producer of a new commodity, the branded musical experience. Then music (commodified as licenses) is simply one of several inputs, albeit the most important one, to the production process. Accordingly, the devaluation of recorded music would be in the interest of Spotify. If it is true that Spotify is 'not in the music space' but 'in the moment space, this would also mean that Spotify is not just competing with other music streaming or downloading services, but potentially with a broader range of services promising to personalize and optimize everyday activities like studying, exercising or partying.

Music is still commodified by Spotify. But as a commodity, 'music' can mean very different things. It is a concept too vague for allow for a precise analysis of its political economy. Spotify buys music in the form of copyright licenses, bundling it, adding new features, and then sells music as a personalized experience. The market for such a service can be expected to work differently from the market for discrete pieces of recorded sound. Thus, simply asserting that "music" is commodified does not say much at all. When analyzing commodification it is always necessary to ask what kind of object that is made a commodity. A good start is to check where the price tag is hanging. 
Rasmus Fleischer is a postdoctoral researcher based at the Department of Economic History, Stockholm University. His research interests are located in the intersections between culture and economy, as well as technology and politics. Most of all, he has explored 20th century media history, transformations of copyright and the commodification of music. E-mail: rasmus.fleischer@ ekohist.su.se

\section{Notes}

${ }^{1}$ Commodification is not the same as commoditization. While the first term has to do with a movement into the market, the latter stands for a change in the mechanisms of competition on the market. Commoditization implies that buyers no longer pay attention to the particular brand of a product, but regards it more as an undifferentiated material like sugar, oil or electricity (the alternative sense of "commodity"). This concept was established in business theory in the 1990s. Before that, the two terms were used interchangeably.

${ }^{2}$ According to Marx, it is not labour but labour-power that is commodified under capitalism. Indeed, the whole riddle of exploitation is located in this distinction. Labour-power is the capacity to perform labour. By buying labour-power, the capitalist can exploit labour and retain the results of surplus-labour (Marx 1867/1962: 181-191, Clarke 1982: 89, Postone 1991: 270, Heinrich 2012: 91).

${ }^{3}$ It can be noted that Taylor (2015) departs from his own earlier claim (Taylor 2006), that digital media was bringing about a wholly new regime of commodification, with some new openings toward a de-commodified experience of music - a line of thought reminiscent of Jacques Attali (1985, 133-148). Taylor's distinction between the residual, the dormant and the emergent is borrowed from Raymond Williams (1973).

${ }^{4}$ Technically, streaming is downloading. The only difference is what happens to the data after it is downloaded: either it is placed in volatile memory for immediate playback (streaming), or it is saved in a more permanent way (downloading).

${ }^{5}$ In a strict economic sense, it could be argued that price competition has not been abolished, but only reduced to the binary choice between charging something and charging nothing. Those who want to promote their music by charging nothing for it may choose distribution platforms like YouTube or SoundCloud. 


\section{Culture Unbound}

Journal of Current Cultural Research

\section{References}

Akst, Daniel (2005): “Unbundles of Joy", The New York Times, Dec. 11

Appadurai, Arjun (1986): "Introduction: Commodities and the Politics of Value", Arjun Appadurai (ed.), The Social Life of Things: Commodities in Cultural Perspective, Cambridge: Cambridge University Press, 3-64.

Attali, Jacques (1985): Noise. The Political Economy of Music, Minneapolis: University of Minnesota Press.

Beech, Dave (2015): Art and Value. Art's Economic Exceptionalism in Classical, Neoclassical and Marxist Economics, Chicago: Haymarket Books.

Carr, Nicholas (2008): The Big Switch: Rewiring the World, from Edison to Google, New York: Norton.

Clarke, Simon (1982): Marx, Marginalism and Modern Sociology: from Adam Smith to Max Weber, London: Macmillan.

Elberse, Anita (2010): "Bye Bye Bundles: The Unbundling of Music in Digital Channels", Journal of Marketing 74:3.

Fleischer, Rasmus (2012): Musikens politiska ekonomi. Lagstiftningen, ljudmedierna och försvaret av den levande musiken, 1925-2000, Stockholm: Ink bokförlag.

Fleischer, Rasmus (2015): "Towards a Postdigital Sensibility: How to get Moved by too Much Music", Culture Unbound 7, 255-269.

Fleischer, Rasmus \& Pelle Snickars (2017): "Discovering Spotify - A Thematic Introduction", Culture Unbound, 9:1, 1-16.

Galuszka, Patryk (2015): "Music Aggregators and Intermediation of the Digital Music Market", International Journal of Communication 9.

Graeber, David (2001): Toward an Anthropological Theory of Value. The False Coin of our own dreams, New York: Palgrave.

Haug, Wolfgang Fritz (2010): "Kommodifizierung", in Wolfgang Fritz Haug, Frigga Haug und Peter Jehle (eds.), Historisch-kritisches Wörterbuch des Marxismus, Bd 7/2, Knechtschaft bis Krise des Marxismus, columns 1243-1255, Hamburg: Argument.

Heinrich, Michael (2012): An Introduction to the Three Volumes of Karl Marx's Capital, New York: Monthly Review Press.

IFPI (2007): “Digital Music Report 2007”, available at: http://www.ifpi.org/content/ library/digital-music-report-2007.pdf (accessed 09/09/16).

Jameson, Fredric (2009): Valences of the Dialectic, London: Verso.

Johansson, Daniel (2013): "From Products to Consumption. Changes on the Swedish Music Market as a Result of Streaming Technologies”, Working Paper, Linnaeus University, Sweden.

Kopytoff, Igor (1986): "The Cultural Biography of Things: Commodization as Process", Arjun Appadurai (ed): The Social Life of Things. Commodities in a Cultural Perspective, Cambridge: Cambridge University Press, 64-91.

Kurz, Robert (2012) Geld ohne Wert: Grundrisse zu einer Transformation der Kritik der politischen ökonomie, Berlin: Horlemann.

Lukács, Georg (1923/1971): "Reification and the Consciousness of the Proletariat", in History and Class Consciousness: Studies in Marxist Dialectics, London: Merlin Press.

Martin, Stewart (2007): "The Absolute Artwork Meets the Absolute Commodity", Radical Philosophy 146, 15-25.

Marx, Karl (1867/1962): Das Kapital: Kritik der politischen Ökonomie. Erster Band: Der Produktionsprozeß des Kapitals, reprinted as Marx-Engels-Werke (MEW), volume 23, Berlin: Dietz Verlag.

Marx, Karl (1885/1963): Das Kapital: Kritik der politischen Ökonomie. Zweiter Band: Der Zirkulationsprozeß des Kapitals, reprinted as Marx-Engels-Werke (MEW), volume 24, Berlin: Dietz Verlag. 
Manzerolle, Vincent R. \& Atle Mikkola Kjøsen (2012): "The Communication of Capital: Digital Media and the Logic of Acceleration", Triple C 10 (2), 214-229.

Morris, Jeremy Wade (2015): Selling Digital Music, Formatting Culture, Oakland: University of California Press.

Morris, Jeremy Wade \& Devon Powers (2015): "Control, Curation and Musical Experience in Streaming Music Services", Creative Industries Journal 8 (2), pp. $106-122$.

Pakman, David (2011): "The Unbundling of Media", blog post available at: http:// www.pakman.com/2011/04/15/the-unbundling-of-media/ (accessed 16/03/17).

Postone, Moishe (1993) Time, Labor, and Social Domination. A reinterpretation of Marx's Critical Theory, Cambridge: Cambridge University Press.

Reitman, Rainey (2016) "The Kafkaesque Battle of Soulseek and PayPal, and Why Free Speech Defenders Should be Worried About Payment Networks", Electronic Frontier Foundation, February 25, available at: http://www.ifpi.org/content/library/digital-music-report-2007.pdf (accessed 16/03/17).

Rose, Carol (2005): "Afterword: Wither Commodification", Martha M. Ertman \& Joan C. Williams (eds.): Rethinking Commodification: Cases and Readings in Law and Culture, New York: New York University Press, 402-428.

Seabrook, John (2014): "Revenue Streams. Is Spotify the Music Industry’s Friend or its Foe?", The New Yorker, November 24, 2014.

Sterne, Jonathan (2012): MP3. The Meaning of a Format, Durham: Duke University Press.

Styvén, Maria (2007): Exploring the Online Music Market. Consumer Characteristics and Value Perceptions, diss. Luleå tekniska universitet.

Söderberg, Johan (2008): Hacking Capitalism. The Free and Open Source Software Movement, New York: Routledge.

Taylor, Timothy D. (2006): "Music + Digital Culture: New Forms of Consumption and Commodification", Paul Messaris \& Lee Humphreys (eds.): Digital Media: Transformations in Human Communication, New York: Lang, 87-96.

Taylor, Timothy D. (2007): "The Commodification of Music at the Dawn of the Era of "Mechanical Music"', Ethnomusicology 51 (2), 281-305.

Taylor, Timothy D. (2015): Music and Capitalism. A History of the Present, Chicago: The University of Chicago Press.

Waelbroeck, Patrick (2013): "Digital Music: Economic Perspectives". Available at SSRN: https://ssrn.com/abstract=2249690 or http://dx.doi.org/10.2139/ ssrn.2249690

Wikström, Patrik (2009): The Music Industry: Music in the Cloud, Cambridge: Polity.

Williams, Raymond (1973) "Base and Superstructure in Marxist Cultural Theory", New Left Review I (82). 